\title{
CYCLANILIDE TREATMENTS INCREASE LATERAL BRANCHING OF APPLE AND PEAR NURSERY TREES
}

\author{
SARACOGLU, O.*-CEBE, U. \\ Department of Horticulture, Faculty of Agriculture, University of Gaziosmanpasa \\ Tokat, Turkey \\ (phone: +90-356-252-1616/ext. 2109; fax: +90-356-252-1488) \\ *Corresponding author \\ e-mail: onur.saracoglu@gop.edu.tr, onursaracoglu60@gmail.com
}

(Received 21 $1^{\text {st }}$ May 2018; accepted $11^{\text {th }}$ Jul 2018)

\begin{abstract}
This study was carried out to investigate the effects of different cyclanilide (Cyc) and Perlan (Pr) doses on formation of lateral branches on apple [Golden Delicious (GD) and Starking Delicious (SD)] and pear (Deveci and Williams) nursery trees grafted on seedling rootstocks. Except for $5 \mathrm{mg} \mathrm{L}^{-1} \mathrm{Cyc}$ in Deveci pears, all Cyc concentrations applied in this study increased significantly the number of lateral branches on both apple and pear trees in nursery. In GD apple, while control trees had 2.5 lateral branches, the trees treated $100 \mathrm{mg} \mathrm{L}^{-1}$ Cyc had 12.7 lateral branches per trees. Except for $250 \mathrm{mg} \mathrm{L}^{-1}$ in GD apple, all other Pr treatments did not cause a significant increase in the number of lateral branches on apple and pear trees. Crotch angles of SD apples decreased significantly with $750 \mathrm{mg} \mathrm{L}^{-1} \mathrm{Pr}$ treatments. The 250 and $500 \mathrm{mg} \mathrm{L}^{-1}$ Pr treatments significantly reduced number of lateral branches of Williams pears. It was concluded based on present findings that entire Cyc doses could be used as an efficient tool to increase the number of lateral branches in apples and pears; high Cyc doses could also be used to reduce the first branch height in both apple cultivars and Deveci pears.
\end{abstract}

Keywords: auxin, benzyladenine, bio-regulator, feather, perlan

\section{Introduction}

For a profitable fruit growing, there are many factors to consider when establishing an orchard. These factors include rootstock, cultivar, tree density, training system, pruning methods and support systems. The primary target of the systems developed for the orchards is to maintain high yield levels through early and late yields and to get exceptional fruit quality (Robinson, 2003). The basic factor for early production is to get fruits from the initial years. Therefore, branched trees are used while establishing orchards (Coşkun, 2011). Number of lateral branches, crotch angle and the first branch height are significant factors in having early and high yields (Barritt, 1992; Hrotko et al., 1996; Kviklys, 2006; Koyuncu and Yıldırım, 2008; Magyar et al., 2008).

The formation of lateral branches can be controlled through external applications of growth regulators effective in apical dormancy. Cytokinins are known to inhibit apical. Previous researches indicated that benzyladenine (BA), a synthetic cytokinin, stimulated lateral branch formation (Faust, 1989; Atay and Koyuncu, 2016; Ipek et al., 2017). Perlan $(\mathrm{Pr})$ or Promolin $\left(\mathrm{BA}+\mathrm{GA}_{4+7}\right)$ have an active ingredient of cytokinins and gibberellin and these commercial products were also reported to stimulate lateral branch formation in different fruit species (Cody et al., 1985; Elfving, 1985; Y1ldırım et al., 2010). Another approach to stimulate lateral branch formation is to inhibit transport of auxins which stimulate apical dormancy. It was reported in previous studies that 2,3,5-triiodobenzoic acid and n-propyl-3-t-butylphenoxyacetate and similar chemicals inhibited polar auxin transport and increased the number of lateral branches (Jacyna and Dodds, 2001). Cyclanilide (Cyc) has emerged as a bio-regulator inhibiting auxin transport and it was 
reported in previous studied that Cyc stimulated shooting of lateral buds in different fruit species (Tamas, 1995; Mickelbart, 2011). On the other hand, effects of such chemicals usually vary based on species and cultivars (Wustenberghs and Keulemans, 1999). Previous studies were mostly carried out over the trees grafted on clonal dwarfing rootstocks. On the other hand, in Turkey, nursery trees grafted on seedling rootstocks are still used at considerable rates in apples and pears. These trees generally yield late because of strong vegetative growth. Therefore, in nursery trees grafted on strong rootstocks, breaking apical dormancy and stimulating lateral-branch formation are even more important. This study was conducted to investigate the effects of Cyc and $\mathrm{Pr}$ treatments at different doses on lateral branch formation in Golden Delicious and Starking Delicious apple cultivars and Williams and Deveci pear cultivars grafted on seedling rootstocks.

\section{Materials and methods}

\section{Plant material}

This study was conducted in a commercial nursery orchard in Tokat (Turkey) located between $40^{\circ} 18^{\prime}$ north latitude and $36^{\circ} 13^{\prime}$ east longitude in 2015 . Experimental site has a loamy soil texture with moderate lime, low organic matter, sufficient $\mathrm{P}_{2} \mathrm{O}_{5}$ and $\mathrm{K}_{2} \mathrm{O}$ levels. Annual average temperature (based on 55-years data) is $12.6{ }^{\circ} \mathrm{C}$, average relative humidity is $62.8 \%$ and average precipitation is $432.1 \mathrm{~mm}$ (Tokat Meteoroloji Station). In the study years average temperature, average relative humidity and average precipitation are measured as in $13.1{ }^{\circ} \mathrm{C}, 62.7 \%$ and $318.1 \mathrm{~mm}$, respectively. Fertilization was performed in all experimental plots in accordance with the results of soil analyses. Irrigations were performed with drip irrigation. Golden Delicious (GD) and Starking Delicious (SD) apple cultivars were grafted on apple seedling rootstocks (Malus domestica L), Williams and Deveci pear cultivars were grafted on pear seedling rootstocks (Pyrus communis L.) with T-budding.

\section{Treatment}

\section{Concentration}

Apple nursery trees were subjected to 250, 500, 750 and $1000 \mathrm{mg} \mathrm{L}^{-1}$ Perlan (18.8\% 6benzyladenine (BA) and 18.5\% GA4+7) and 25, 50, 75 and $100 \mathrm{mg} \mathrm{L}^{-1}$ Cyclanilide (Cyc) treatments; pear trees were subjected to 250 and $500 \mathrm{mg} \mathrm{L}^{-1}$ Perlan and 5, 10, 15 and 20 $\mathrm{mg} \mathrm{L} \mathrm{L}^{-1}$ Cyclanilide treatments. All experimental solutions were applied with $0.1 \%$ surfactant. Control trees were subjected to only distilled water treatments with surfactant.

\section{Experimental design}

Nursery trees were planted with $80 \mathrm{~cm}$ plant spacing and $15 \mathrm{~cm}$ row spacing. Standard cultural practices were performed regularly. All treatments were performed in the first week of July when the trees reached to a height of $70-80 \mathrm{~cm}$ from the soil surface. Treatments were sprayed about $15-20 \mathrm{~cm}$ above the canopy.

\section{Investigated parameters}

At the end of growth season, tree trunk diameter, tree height, lateral branch length, height of the first branch, crotch angle, number of lateral branches were determined. 
Trunk diameter was measured with a caliper from $5 \mathrm{~cm}$ above the graft union. Tree height was measured as the height from the graft union to tip of the tree. Lateral branches longer than $10 \mathrm{~cm}$ were counted in each tree to get number of lateral branches per tree. Their lengths were measured to get average lateral branch length. The crotch angle was measured with a protractor. The height of first branch was taken as the distance from the bud union to the first induced feather longer than $10 \mathrm{~cm}$.

\section{Statistical analysis}

Experiments were conducted in randomized block design with 3 replications with 10 trees in each replicate. The normality of the data was confirmed by the KolmogorovSmirnov test and the homogeneity of variances by the Levene's test. Except for number of lateral branches, resultant data were subjected to variance analysis. Means were separated by Duncan's multiple range test. Since the number of lateral branches did not have a normal distribution, they were analyzed with Friedman test.

\section{Results}

As compared to control treatment, neither Cyc nor Pr treatment resulted in significant changes in trunk diameters of either apple cultivars (Table 1). A similar response was observed in tree heights. Relative to control treatment, decreases in tree height were observed only with $100 \mathrm{mg} \mathrm{L}^{-1}$ Cyc and $750 \mathrm{mg} \mathrm{L}^{-1} \mathrm{Pr}$ treatments of SD cultivar. Experimental treatments did not result in significant differences in lateral branch lengths of GD. Although some treatments created differences in lateral branch lengths of SD cultivar, both Cyc and $\operatorname{Pr}$ treatments did not result in significant changes in lateral branch lengths as compared to control treatments.

Table 1. Effects of cyclanilide and perlan treatments on trunk diameter, sapling height, lateral branch length of Golden Delicious and Starking Delicious apple cultivars

\begin{tabular}{c|c|c|c}
\hline \multirow{2}{*}{ Treatments $\left(\mathbf{m g ~ L ^ { - 1 }}\right)$} & Trunk diameter (mm) & Tree height (cm) & Branch length (cm) \\
\cline { 2 - 4 } & \multicolumn{3}{|c}{ Golden Delicious } \\
\hline Control & $14.1 \mathrm{ab} *$ & $171.5 \mathrm{a}$ & $41.9 \mathrm{a}$ \\
$25 \mathrm{Cyc}$ & $13.6 \mathrm{ab}$ & $159.7 \mathrm{a}$ & $30.8 \mathrm{a}$ \\
$50 \mathrm{Cyc}$ & $15.62 \mathrm{a}$ & $171.6 \mathrm{a}$ & $33.5 \mathrm{a}$ \\
$75 \mathrm{Cyc}$ & $14.65 \mathrm{ab}$ & $154.8 \mathrm{a}$ & $31.6 \mathrm{a}$ \\
$100 \mathrm{Cyc}$ & $14.8 \mathrm{ab}$ & $157.5 \mathrm{a}$ & $29.9 \mathrm{a}$ \\
$250 \mathrm{Pr}$ & $16.0 \mathrm{a}$ & $174.3 \mathrm{a}$ & $33.8 \mathrm{a}$ \\
$500 \mathrm{Pr}$ & $16.3 \mathrm{a}$ & $180.6 \mathrm{a}$ & $30.5 \mathrm{a}$ \\
$750 \mathrm{Pr}$ & $14.6 \mathrm{ab}$ & $160.3 \mathrm{a}$ & $39.1 \mathrm{a}$ \\
$1000 \mathrm{Pr}$ & $12.0 \mathrm{~b}$ & $140.9 \mathrm{a}$ & $38.6 \mathrm{a}$ \\
\hline & & $211.7 \mathrm{a}$ & $50.6 \mathrm{ab}$ \\
Control & $16.3 \mathrm{ab}$ & $198.1 \mathrm{ab}$ & $49.9 \mathrm{ab}$ \\
$25 \mathrm{Cyc}$ & $16.9 \mathrm{a}$ & $179.1 \mathrm{ab}$ & $40.5 \mathrm{ab}$ \\
$50 \mathrm{Cyc}$ & $15.0 \mathrm{ab}$ & $175.8 \mathrm{ab}$ & $36.3 \mathrm{ab}$ \\
$75 \mathrm{Cyc}$ & $15.1 \mathrm{ab}$ & $160.0 \mathrm{~b}$ & $32.6 \mathrm{~b}$ \\
$100 \mathrm{Cyc}$ & $13.1 \mathrm{ab}$ & $173.9 \mathrm{ab}$ & $56.3 \mathrm{a}$ \\
$250 \mathrm{Pr}$ & $13.5 \mathrm{ab}$ & $191.3 \mathrm{ab}$ & $38.1 \mathrm{ab}$ \\
$500 \mathrm{Pr}$ & $15.2 \mathrm{ab}$ & $150.6 \mathrm{~b}$ & $29.3 \mathrm{~b}$ \\
$750 \mathrm{Pr}$ & $12.6 \mathrm{~b}$ & $170.2 \mathrm{ab}$ & $30.3 \mathrm{~b}$ \\
\hline $1000 \mathrm{Pr}$ & $14.5 \mathrm{ab}$ & &
\end{tabular}

*Means in the same columns with the same letter do not differ according to Duncan's test at $\mathrm{P}<0.05$ 
Low Cyc doses did not have significant effects on the first lateral branch height. However, higher doses (75 and $\left.100 \mathrm{mg} \mathrm{L}^{-1}\right)$ result in significant decreases in both cultivars (Table 2). All Pr doses did not cause a significant change in the first lateral branch height of GD apples. In the SD apple tree, while $1000 \mathrm{mg} \mathrm{L}^{-1} \mathrm{Pr}$ treatment decreased the first lateral branch height, effects of the other doses were not significant when compared to control treatment. Crotch angles of SD cultivar significantly decreased only with $750 \mathrm{mg} \mathrm{L}^{-1}$ Pr treatment. Effects of the other treatments were not found to be significant.

Table 2. Effects of cyclanilide and perlan treatments on the first branch height and crotch angle of Golden Delicious and Starking Delicious apple cultivars

\begin{tabular}{c|c|c}
\hline \multirow{2}{*}{ Treatments $\left(\mathbf{m g ~ \mathbf { L } ^ { - 1 }}\right)$} & Height of the first branch (cm) & Crotch angle $\left.\mathbf{(}^{\circ}\right)$ \\
\cline { 2 - 3 } & \multicolumn{2}{|c}{ Golden Delicious } \\
\hline Control & $71.2 \mathrm{a}^{*}$ & $56.2 \mathrm{ab}$ \\
$25 \mathrm{Cyc}$ & $55.0 \mathrm{abc}$ & $58.4 \mathrm{ab}$ \\
$50 \mathrm{Cyc}$ & $39.9 \mathrm{abc}$ & $59.2 \mathrm{ab}$ \\
$75 \mathrm{Cyc}$ & $33.9 \mathrm{bc}$ & $61.6 \mathrm{a}$ \\
$100 \mathrm{Cyc}$ & $20.7 \mathrm{c}$ & $62.2 \mathrm{a}$ \\
$250 \mathrm{Pr}$ & $69.2 \mathrm{ab}$ & $55.1 \mathrm{ab}$ \\
$500 \mathrm{Pr}$ & $72.0 \mathrm{a}$ & $55.4 \mathrm{ab}$ \\
$750 \mathrm{Pr}$ & $63.1 \mathrm{ab}$ & $57.6 \mathrm{ab}$ \\
$1000 \mathrm{Pr}$ & $61.1 \mathrm{ab}$ & $51.1 \mathrm{~b}$ \\
\hline & \multicolumn{2}{|c}{ Starking Delicious } \\
\hline Control & $102.0 \mathrm{ab}$ & $77.5 \mathrm{a}$ \\
$25 \mathrm{Cyc}$ & $64.6 \mathrm{bcd}$ & $73.5 \mathrm{a}$ \\
$50 \mathrm{Cyc}$ & $68.3 \mathrm{bcd}$ & $67.0 \mathrm{a}$ \\
$75 \mathrm{Cyc}$ & $42.9 \mathrm{~d}$ & $65.6 \mathrm{a}$ \\
$100 \mathrm{Cyc}$ & $31.2 \mathrm{~d}$ & $67.5 \mathrm{a}$ \\
$250 \mathrm{Pr}$ & $111.3 \mathrm{a}$ & $70.6 \mathrm{a}$ \\
$500 \mathrm{Pr}$ & $98.2 \mathrm{ab}$ & $44.4 \mathrm{~b}$ \\
$750 \mathrm{Pr}$ & $85.8 \mathrm{abc}$ & $66.0 \mathrm{a}$ \\
$1000 \mathrm{Pr}$ & $53.5 \mathrm{~cd}$ & $\mathrm{a}$ \\
\hline
\end{tabular}

*Means in the same columns with the same letter do not differ according to Duncan's test at $\mathrm{P}<0.05$

Entire Cyc treatments remarkably increased the number of lateral branches in both apple cultivars. While the number of lateral branches was 2.5 in control treatment of GD cultivar, the value increased to 12.7 with $100 \mathrm{mg} \mathrm{L}^{-1}$ Cyc treatment. In GD cultivar, significant differences were observed in number of lateral branches the among the Cyc application concentrations. Number of lateral branches in 50,75 and $100 \mathrm{mg} \mathrm{L}^{-1} \mathrm{Cyc}$ treatments was remarkably higher than both the control and $25 \mathrm{mg} \mathrm{L}^{-1}$ Cyc treatment. Similarly, Cyc treatments increased number of lateral branches also in SD cultivar, but the differences between Cyc doses were not found to be significant. On the other hand, effects of Pr doses on number of lateral branches varied based on the cultivar and treatment dose. Relative to control treatment, only $250 \mathrm{mg} \mathrm{L}^{-1} \mathrm{Pr}$ treatment significantly increased number of lateral branches in GD cultivar (Fig. 1).

No treatment was significantly different from each other and control with respect to trunk diameters and tree heights in Deveci and Williams pear cultivars. The differences in lateral branch lengths of the treatments were not found to be significant in Williams cultivar. In Deveci cultivar, $250 \mathrm{mg} \mathrm{L}^{-1}$ Pr-treated trees had significantly higher tree 
height than 15 and $20 \mathrm{mg} \mathrm{L}^{-1}$ Cyc-treated trees, but no treatment caused a significant change relatively to control (Table 3).

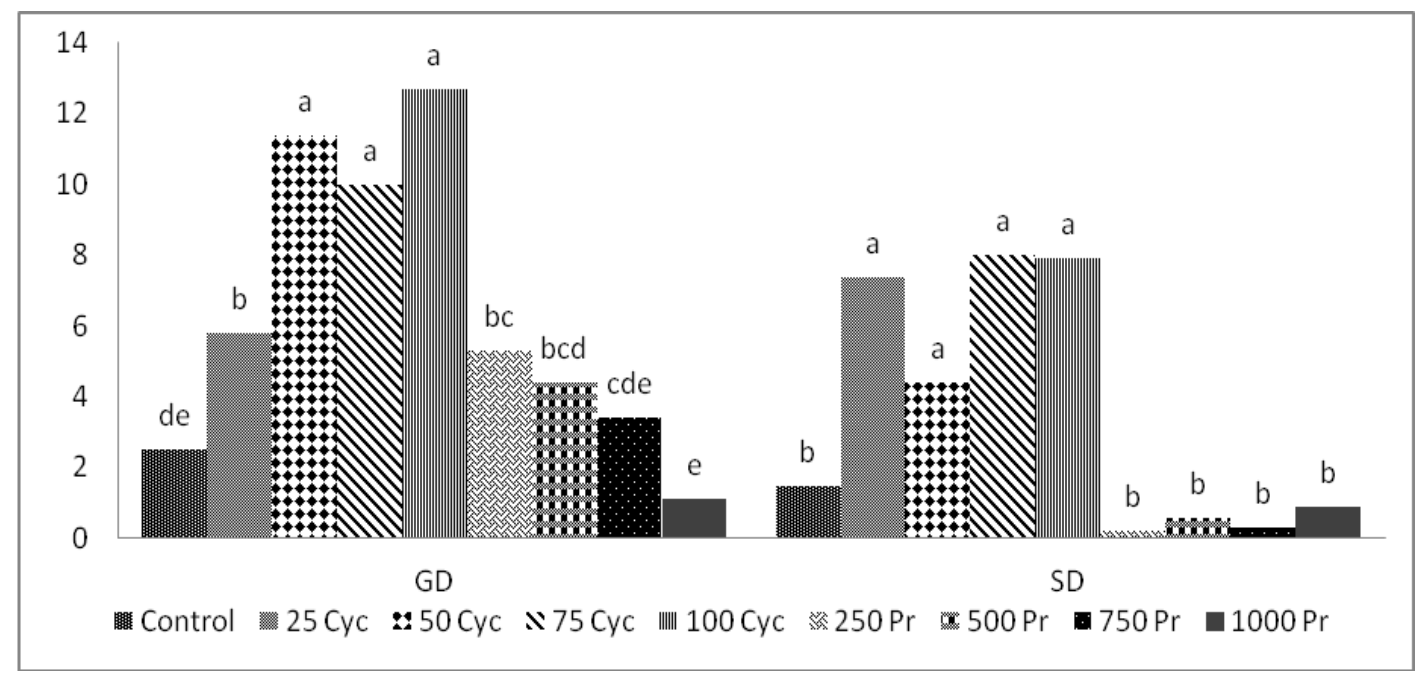

Figure 1. Effects of cyclanilide and perlan treatments on the number of lateral branches of Golden Delicious and Starking Delicious apple cultivars

Table 3. Effects of cyclanilide and perlan treatments on trunk diameter, sapling height and lateral branch length of Deveci and Williams pear cultivars

\begin{tabular}{|c|c|c|c|}
\hline \multirow{2}{*}{ Treatments $\left(\mathrm{mg} \mathrm{L}^{-1}\right)$} & Trunk diameter (mm) & Tree height $(\mathrm{cm})$ & Branch length $(\mathrm{cm})$ \\
\hline & \multicolumn{3}{|c|}{ Deveci } \\
\hline Control & $12.84 \mathrm{a}^{*}$ & $153.27 \mathrm{a}$ & $25.36 \mathrm{ab}$ \\
\hline 5 Cyc & $10.78 \mathrm{a}$ & $115.60 \mathrm{a}$ & $25.51 \mathrm{ab}$ \\
\hline 10 Cyc & $11.12 \mathrm{a}$ & $114.33 \mathrm{a}$ & $21.25 \mathrm{ab}$ \\
\hline 15 Cyc & $12.87 \mathrm{a}$ & $123.47 \mathrm{a}$ & $19.04 \mathrm{~b}$ \\
\hline 20 Cyc & $11.49 \mathrm{a}$ & $115.07 \mathrm{a}$ & $18.31 \mathrm{~b}$ \\
\hline $250 \mathrm{Pr}$ & $11.31 \mathrm{a}$ & $123.93 \mathrm{a}$ & $29.69 \mathrm{a}$ \\
\hline \multirow[t]{2}{*}{$500 \operatorname{Pr}$} & $12.03 \mathrm{a}$ & $140.20 \mathrm{a}$ & $25.57 \mathrm{ab}$ \\
\hline & \multicolumn{3}{|c|}{ Williams } \\
\hline Control & $12.16 \mathrm{a}$ & $126.80 \mathrm{a}$ & $12.50 \mathrm{a}$ \\
\hline 5 Cyc & $13.46 \mathrm{a}$ & $123.60 \mathrm{a}$ & $22.20 \mathrm{a}$ \\
\hline 10 Cyc & $13.90 \mathrm{a}$ & $114.47 \mathrm{a}$ & $18.86 \mathrm{a}$ \\
\hline 15 Cyc & $11.88 \mathrm{a}$ & $106.80 \mathrm{a}$ & $17.91 \mathrm{a}$ \\
\hline $20 \mathrm{Cyc}$ & $11.57 \mathrm{a}$ & $101.07 \mathrm{a}$ & $16.54 \mathrm{a}$ \\
\hline $250 \mathrm{Pr}$ & $11.07 \mathrm{a}$ & $113.27 \mathrm{a}$ & $14.00 \mathrm{a}$ \\
\hline $500 \operatorname{Pr}$ & $11.65 \mathrm{a}$ & $123.53 \mathrm{a}$ & - \\
\hline
\end{tabular}

*Means in the same columns with the same letter do not differ according to Duncan's test at $\mathrm{P}<0.05$

The first branch height and crotch angle of Williams cultivar under Cyc and $\mathrm{Pr}$ treatments were similar to the control treatments. In Deveci cultivar, on the other hand, Pr treatments yielded similar values with the control saplings, but Cyc treatments (except for $5 \mathrm{mg} \mathrm{L}^{-1} \mathrm{Cyc}$ ) significantly reduced the first branch heights. Although the crotch angles of $15 \mathrm{mg} \mathrm{L}^{-1}$ Cyc-treated trees were significantly higher than the crotch angles of $5 \mathrm{mg} \mathrm{L}^{-1}$ Cyc-treated trees, both treatment did not differ from control treatment respect to crotch angle (Table 4). 
Table 4. Effects of cyclanilide and perlan treatments on the first branch height and crotch angle of Deveci and Williams pear cultivars

\begin{tabular}{c|c|c}
\hline \multirow{2}{*}{ Treatments $\left(\mathrm{mg} \mathrm{L}^{-1}\right)$} & Height of the first branch (cm) & Crotch angle $\left.\mathbf{(}^{\circ}\right)$ \\
\cline { 2 - 3 } & $127.00 \mathrm{a}^{*}$ & $35.93 \mathrm{ab}$ \\
Control & $93.33 \mathrm{ab}$ & $34.07 \mathrm{~b}$ \\
$5 \mathrm{Cyc}$ & $72.35 \mathrm{~b}$ & $45.67 \mathrm{ab}$ \\
$10 \mathrm{Cyc}$ & $71.05 \mathrm{~b}$ & $49.42 \mathrm{a}$ \\
$15 \mathrm{Cyc}$ & $64.43 \mathrm{~b}$ & $43.61 \mathrm{ab}$ \\
$20 \mathrm{Cyc}$ & $97.93 \mathrm{ab}$ & $38.31 \mathrm{ab}$ \\
$250 \mathrm{Pr}$ & $113.53 \mathrm{a}$ & $43.00 \mathrm{ab}$ \\
$500 \mathrm{Pr}$ & \multicolumn{2}{|c|}{ Williams } \\
\hline & $47.80 \mathrm{a}$ & $41.17 \mathrm{a}$ \\
Control & $69.75 \mathrm{a}$ & $51.46 \mathrm{a}$ \\
$5 \mathrm{Cyc}$ & $48.97 \mathrm{a}$ & $50.97 \mathrm{a}$ \\
$10 \mathrm{Cyc}$ & $54.01 \mathrm{a}$ & $47.72 \mathrm{a}$ \\
$15 \mathrm{Cyc}$ & $42.07 \mathrm{a}$ & $44.19 \mathrm{a}$ \\
$20 \mathrm{Cyc}$ & $59.00 \mathrm{a}$ & $40.00 \mathrm{a}$ \\
$250 \mathrm{Pr}$ & - & - \\
$500 \mathrm{Pr}$ & &
\end{tabular}

*Means in the same columns with the same letter do not differ according to Duncan's test at $\mathrm{P}<0.05$

The experimental treatments had significant effects on number of lateral branches in both pear cultivars. Except for $5 \mathrm{mg} \mathrm{L}^{-1}$ Cyc treatment, other Cyc treatments significantly increased number of lateral branches in Deveci cultivar. In this pear cultivar, while the number of lateral branches per tree was 0.93 in control treatment, the value increased to 5.68 with $15 \mathrm{mg} \mathrm{L}^{-1}$ Cyc treatment. Number of lateral branches in Prtreated trees of Deveci cultivar was similar with the control treatment. In Williams cultivar, all Cyc treatments significantly increased number of lateral branches. However, both $\operatorname{Pr}$ doses significantly reduced the number of lateral branches. As compared to $5 \mathrm{mg} \mathrm{L}^{-1}$ Cyc treatment, 10 and $15 \mathrm{mg} \mathrm{L}^{-1}$ Cyc treatments were significantly more effective on increasing number of lateral branches (Fig. 2).

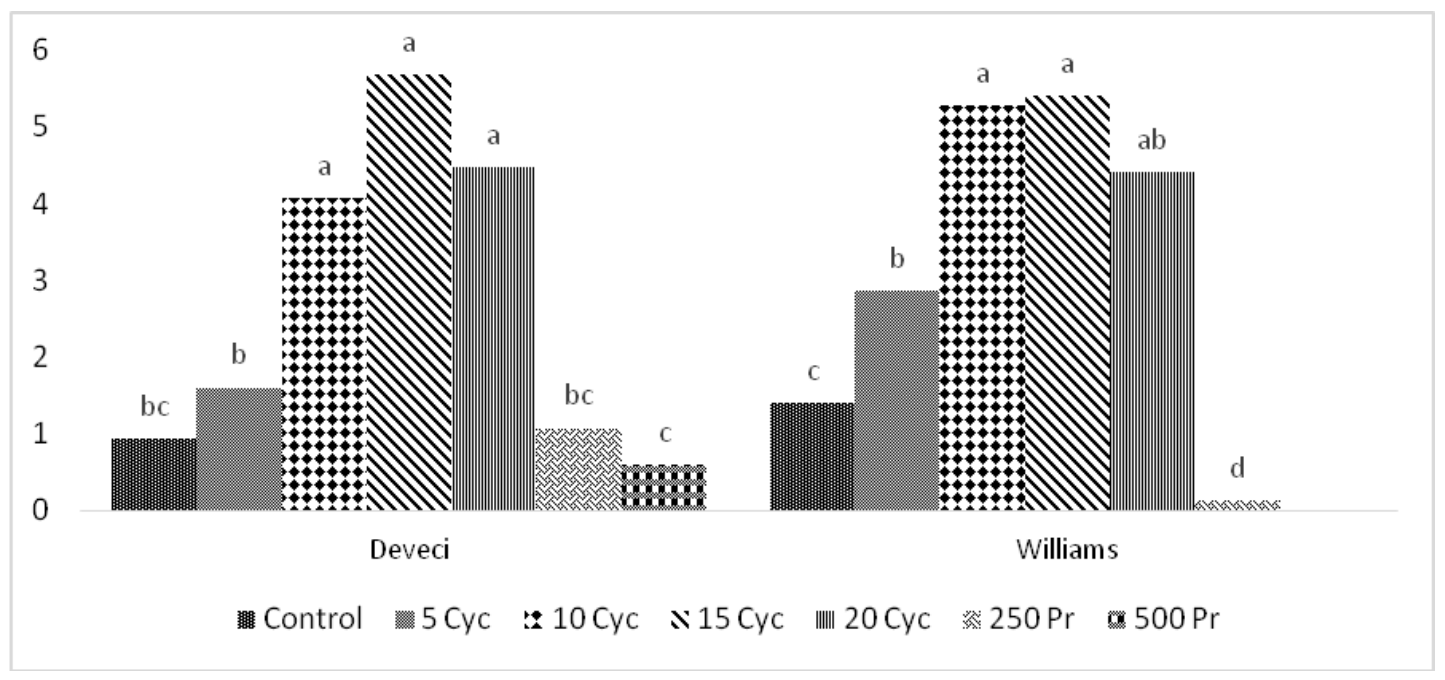

Figure 2. Effects of cyclanilide and perlan treatments on the number of lateral branches of Deveci and Williams pear cultivars 


\section{Discussion}

Cropping is usually delayed in orchards established with trees with less number of lateral branches (Elfving, 2010). Therefore, some plant growth regulators are used to reduce the effects of apical dormancy and thus to stimulate lateral branch development. It was reported in previous studies that benzyladenine (BA) applied either alone or together with gibberellic acid $\left(\mathrm{GA}_{4+7}\right)$ increased number of lateral branches in apple and pear saplings (Neri et al., 2004; Koyuncu and Yıldırım, 2008; Y1ldırım et al., 2010). In present study, the effects of Pr treatments varied based on species and cultivars. More efficient and stable outcomes were achieved from Cyc treatments. Even remarkable at higher doses, all Cyc treatments distinctively increased number of lateral branches both in apples and pears. A similar case was reported by Elfving and Visser (2006a) for cherry saplings. Previous researchers also indicated that Cyc treatments yielded better outcomes for lateral branch development than Promalin $\left(B A+\mathrm{GA}_{4+7}\right)$. Researchers also indicated that the effects of Promalin varied based on species, but Cyc had more stable outcomes for different species (Elfving and Visser, 2006a, b; Ipek et al., 2017; Lordan et al., 2017).

Previous researchers indicated that the effects of both Pr and Cyc on trunk diameter and tree height varied depending on species, cultivars, rootstocks and treatment doses (Gastol and Poniedzialek, 2003; Rossi et al., 2004; Elfving and Visser, 2006a, b; Kalyoncu et al., 2011; Sazo and Robinson, 2011; Moghadam and Zamanipour, 2013; Lordan et al., 2017). However, none of these studies mentioned about a negative impact of those treatments on nursery tree quality parameters. In present study, both Pr and Cyc treatments generally did not have any negative effects on trunk diameter and tree height of apple (GD and SD) and pear (Deveci and Williams) cultivars.

Some researchers reported that BA and Promalin treatments increase lateral branch lengths of apple saplings (Greene et al., 1990; Kalyoncu et al., 2011). Gastol and Poniedzialek (2003) carried out a study with 3 different apple cultivars and indicated that effects of Promalin treatments on lateral branch lengths varied with the years and climate conditions. Elfving and Visser (2005) reported that different Cyc doses did not result in significant changes in lateral branch lengths of Cameo apples grafted on M26 rootstocks, but significantly reduced lateral branch lengths of Fuji apples. Despite the differences in lateral branch lengths of treatments in Deveci pear and Starking Delicious apple cultivar, none of the treatments resulted in significant changes in lateral branch lengths of apples and pears as compared to the control treatments. Such findings revealed that response of nursery trees to Pr and Cyc treatments with regard to lateral branch length might vary based on the rootstocks and cultivars.

Although being changed based on intended market, the first branch height is a significant criterion for all markets. Contradictory outcomes were reported in previous studies about the effects of Pr and Cyc treatments on the first branch heights (Elfving and Visser, 2005, 2006b; Y1ldirım et al., 2010; Sazo and Robinson, 2011). Except for Williams cultivar, Cyc treatments decreased the first branch height of the nursery trees, on the other hand Pr treatments generally did not have significant effects on the first branch heights. In previous studies, positive effects of Promalin and Cyc-like growth regulators on crotch angles were reported (Gürz, 2005; Y1ldırım et al., 2010). However in this study, no results were obtained to support that both Pr and Cyc could have a beneficial effect on crotch angles of nursery trees of apple and pear cultivars. 


\section{Conclusion}

Although there are several studies indicating that external application of growth regulators effective in apical dormancy may stimulate lateral branch formation in fruit trees, effects of such growth regulators usually vary based on the rootstock and cultivars. Present findings revealed that all Cyc doses could be used to increase number of lateral branches in apple (Golden Delicious and Starking Delicious) and pear (Deveci and Williams) cultivars grafted on seedling rootstocks; Cyc doses could be used as an efficient tool to reduce the first branch height in two apple cultivars and Deveci pear cultivar. Also, these growth regulators stimulated shooting of lateral buds through inhibiting apical dormancy and did not have any negative impacts on tree heights.

\section{REFERENCES}

[1] Atay, A. N., Koyuncu, F. (2016): Manipulating regular bearing in 'Golden Delicious'/M9 apple trees using GA4+ 7 and ethephon. - International Journal of Fruit Science 16: 1022.

[2] Barritt, B. H. (1992): Intensive Orchard Management. Good Fruit Grower. - Yakima, Washington.

[3] Cody, C. A., Larsen, F. E., Fritts, Jr. R. (1985): Stimulation of lateral branch development in tree fruit nursery stock with GA4+7+BA. - Hortscience 20: 758-759.

[4] Coşkun, N. (2011): Effect of plant growth promoting rhizobacteria (PGPR) and perlan (BA+GA4+7) applications on branching of some apple cultivars saplings grafted M9. Ms. Thesis, Selçuk University, Graduate School of Natural and Applied Sciences, pp. 137.

[5] Elfving, D. C. (1985): Comparison of cytokinin and apical-dominance-inhibiting growth regulators for lateral-branch induction in nursery and orchard apple trees. - Journal of Horticultural Science 60: 447-454.

[6] Elfving, D. C., Visser, D. B. (2005): Cyclanilide induces lateral branching in apple trees. - Hortscience 40: 119-122.

[7] Elfving, D. C., Visser, D. B. (2006a): Cyclanilide induces lateral branching in sweet cherry trees. - Hortscience 41: 149-153.

[8] Elfving, D. C., Visser, D. B. (2006b): Timing cyclanilide and cytokinin applications in the nursery to obtain desired lateral branch height in apple and sweet cherry trees. Hortscience 41: 1238-1242.

[9] Elfving, D. C. (2010): Plant bioregulators in the deciduous fruit tree nursery. - Acta Horticulturae 884: 159-166.

[10] Faust, M. (1989): Physiology of Temperate Zone Fruit Trees. - John Wiley \& Sons, New York.

[11] Gastol, M., Poniedzialek, W. (2003): Induction of lateral branching in nursery trees. Electronic Journal of Polish Agricultural Universities, Horticulture 6: 2.

[12] Greene, D. W., Autio, W. R. (1990): Vegetative responses of apple trees following benzyladenine and growth regulator sprays. - Department of Plant and Soil Sciences, University of Massachusetts, Journal of the American Society for Horticultural Science 115: 400-404.

[13] Gürz, A. (2005): The effect of exogenous benzyl adenine treatment on the lateral branching of apple nursery trees. - Ms. Thesis, Kahramanmaraş Sutcu Imam University, Graduate School of Natural and Applied Sciences, pp. 1-20.

[14] Hrotko, K., Magyar, L., Buban, T. (1996): Improved feathering by benzyladenine application on one year old "Idared" apple trees in the nursery. - Hortscience 28: 49-53. 
[15] Ipek, M., Arikan, Ş., Pirlak, L., Eşitken, A. (2017): Effect of different treatments on branching of some apple trees in nursery. - Erwerbs-Obstbau 59: 119-122.

[16] Jacyna, T., Dodds, K. G. (2001): Preventing limb bareness in young 'Sundrop' apricot trees. - XII International Symposium on Apricot Culture and Decline 701: 679-686.

[17] Kalyoncu, İ. H., Akol, S. Turan, A. (2011): Effects of some chemical and mechanical applications on branching in production of apple nursery trees. - Selçuk Tarım Bilimleri Dergisi 25: 26-32.

[18] Koyuncu, F., Ylldirım, A. N. (2008): Induction of lateral branching of '0900 Ziraat' sweet cherry cultivar in nursery with 6-Benyladenine+GA 4+7. - Acta Horticulture 795: 391-394.

[19] Kviklys, D. (2006): Induction of feathering of planting material. - Latvian Journal of Agronomy 9: 58-63.

[20] Lordan, J., Robinson, T. L., Sazo, M. M., Cowgill, W., Black, B. L., Huffman, L., GriggMcGuffin, K., Francescatto, P., McArtney, S. (2017): Use of plant growth regulators for feathering and flower suppression of apple nursery trees. - HortScience 52: 1080-1091.

[21] Magyar, L., Barancsi, Z., Dickmann, A., Hrotko, K. (2008): Application of biostimulators in nursery. - Bulletin UAS VM, Horticulture 65: 515.

[22] Mickelbart, M. V. (2011): Cyclanilide differentially affects branching in 'Red Maple' cultivars and hybrids. - Journal of Environmental Horticulture 29: 35-38.

[23] Moghadam, E. G., Zamanipour, M. (2013): Induction of lateral branching in sweet cherry (Prunus avium L. cvs. "Siah Mashhad" \& "Dovomras") trees in nursery. Department of Horticulture Agricultural and Natural Resource Research Center of Khorasan Razavi, Mashhad, İran. - Journal of Agricultural Science 5: 3.

[24] Neri, D. Mazzoni, M., Zucconi, F. (2004): Feathering control in sweet cherry (Prunus avium L.) nursery, by deblading and cytokinin. - Acta Horticulture 636: 119-127.

[25] Robinson, T. L. (2003): Apples: Botany, Production and Uses. - In: Ferree, D. C., Warrington, I. J. (eds.). CAB International, pp. 345-407.

[26] Rossi, A. D., Rufato, L., Giacobbo, C. L., Gomes, F. R., Fachinello, C. (2004): Use of promalin on one-year old trees of the apple cv. 'Catarina'. - Acta Horticulture 636: 145 149.

[27] Sazo, M. M., Robinson, T. L. (2011): The use of plant growth regulators for branching of nursery trees in NY State. - New York Fruit Quarterly 19: 2.

[28] Tamas, I. A. (1995): Hormonal Regulation of Apical Dominance. - In: Davies, P. J. (ed.) Plant Hormones and Their Role in Plant Growth and Development. Springer, Dordrecht.

[29] Wustenberghs, H., Keulemans, J. (1999): Le cerisier a fruits doux: amelioration de la qualite des plants. - Le Fruit Belge 67: 106-110.

[30] Yıldırım, A. N., Koyuncu, F., Şan, B., Kaçal, E. (2010): The effect of promalin and heading treatments on lateral shoot formation in pear nursery trees. - Süleyman Demirel University Journal of Natural and Applied Sciences 14: 32-37. 